\title{
Retrospective comparison of the sociodemographic, clinical, radiological and laboratory findings of probable and definitive COVID-19 cases
}

\author{
Olası ve kesin COVID-19 vakalarının sosyodemografik, klinik, radyolojik ve laboratuvar \\ bulgularının retrospektif olarak karşılaştırılması
}

\author{
Erhan Ugurlu, Nazli Cetin, Furkan Ufuk, Nilufer Yigit, Huseyin Gokhan Yavas, Secim Kolak, Ahmet \\ Caliskan, Nese Dursunoglu, Sevin Baser, Goksel Altinisik, Sibel Pekcan
}

\begin{abstract}
Purpose: We aimed to determine the number of possible and precise cases among the patients hospitalized in our clinic and to examine the differences between the sociodemographic, clinical, chest CT and laboratory findings of these two groups.

Materials and methods: The data of all patients hospitalized at the department of pulmonology service between March 13 as the date of the first case and May 5 with probable and definitive COVID-19 were evaluated retrospectively. Patient ward files and hospital data management system were examined. Chest CT findings of the patients were interpreted by two radiologists separately according to the CO-RADS classification blinded to clinical and PCR test results of the patients and then consensus was achieved with joint evaluation.

Results: A total of 99 patients, 38 RT-PCR positive, 61 RT-PCR negative, were included in the study. Neutrophilto-lymphocyte ratio (NLR) values and lymphocyte count were lower at a statistically significant level in positive patients (respectively $p=0.038, p=0.041$ ). Similarly, CRP values were observed to be lower at a statistically significant level in positive patients $(p=0.029)$. When the patients with RT-PCR $(+)$ and RT-PCR $(-)$ but with positive chest CT findings according to CO-RADS staging were compared, the values of WBC, LDH and CRP level was observed to be high were statistically significant in the group with RT-PCR (-) but positive chest CT findings (respectively $p=0,001, p=0,033, p=0,004$ ). The highest AUC value was obtained in the model developed using cough, WBC, LDH, CRP values and thorax CT score, and it was seen that this model could be successful in distinguishing RT-PCR positivity (AUC=0.725, 95\% Cl:0.619-0.830).

Conclusion: In the presence of clinical findings, without waiting for RT-PCR positivity, the probability of COVID-19 disease will increase if there are elevated WBC, CRP and LDH findings with CT findings (stage 4-5 according to CO-RADS).
\end{abstract}

Key words: CO-RADS, probable COVID-19, RT-PCR, SARS-CoV-2.

Ugurlu E, Cetin N, Ufuk F, Yigit N, Yavas HG, Kolak S, Caliskan A, Dursunoglu N, Baser S, Altinisik G, Pekcan S. Retrospective comparison of the sociodemographic, clinical, radiological and laboratory findings of probable and definitive COVID-19 cases. Pam Med J 2021:14:706-716.

Öz

Amaç: Kliniğimizde takip edilen kesin COVID-19 vakalar ile olası COVID-19 vakalar arasındaki sosyodemografik, klinik, BT ve laboratuvar bulgularının farklarını incelemeyi amaçladık.

Erhan Ugurlu, Assoc. Prof. Department of Chest Diseases, Faculty of Medicine, Pamukkale University, Denizli, Turkey, e-mail: drerhanugurlu@ gmail.com (https://orcid.org/0000-0001-5402-6925)

Nazli Cetin, Research Assistant, Department of Chest Diseases, Faculty of Medicine, Pamukkale University, Denizli, Turkey, e-mail: nazlicetin@ yandex.com (https://orcid.org/0000-0002-9077-0580) (Corresponding Author)

Furkan Ufuk, Assoc. Prof. Department of Radiology, Faculty of Medicine, Pamukkale University, Denizli, Turkey, e-mail: furkan.ufuk@hotmail. com (https://orcid.org/0000-0002-8614-5387)

Nilufer Yigit, Research Assistant, Department of Chest Diseases, Faculty of Medicine, Pamukkale University, Denizli, Turkey, e-mail: nilufer_ savurmus@hotmail.com (https://orcid.org/0000-0002-5871-6461)

Huseyin Gokhan Yavas, Research Assistant, Department of Radiology, Faculty of Medicine, Pamukkale University, Denizli, Turkey, e-mail: huseyingokhanyavas@gmail.com (https://orcid.org/0000-0003-4220-3482)

Secim Kolak, Research Assistant, Department of Chest Diseases, Faculty of Medicine, Pamukkale University, Denizli, Turkey, e-mail: secim93@ hotmail.com (https://orcid.org/0000-0002-5406-3459)

Ahmet Caliskan, Assis. Prof. Department of Microbiology, Faculty of Medicine, Pamukkale University, Denizli, Turkey, e-mail: acaliskan@pau. edu.tr (https://orcid.org/0000-0002-1156-3787)

Nese Dursunoglu, Prof. Department of Chest Diseases, Faculty of Medicine, Pamukkale University, Denizli, Turkey, e-mail: ndursunoglu@ yahoo.com (https://orcid.org/0000-0002-6323-3456)

Sevin Baser, Prof. Department of Chest Diseases, Faculty of Medicine, Pamukkale University, Denizli, Turkey, e-mail: basersevin@yahoo.com (https://orcid.org/0000-0002-5538-7754)

Goksel Altinisik, Prof. Department of Chest Diseases, Faculty of Medicine, Pamukkale University, Denizli, Turkey, e-mail: gaergur@gmail.com (https://orcid.org/0000-0001-6869-1301)

Sibel Pekcan, Prof. Department of Chest Diseases, Faculty of Medicine, Pamukkale University, Denizli, Turkey, e-mail: ozkurtsibel@hotmail. com (https://orcid.org/0000-0001-5321-0034) 
Gereç ve yöntem: İlk vaka tarihi olan 13 Mart 2020 ile 5 Mayıs 2020 arasında, olası ve kesin COVID-19 tanısıyla Göğüs Hastalıkları servisinde yatan tüm hastaların verileri retrospektif olarak incelendi. Hastaların toraks BT bulguları, hastaların klinik ve PCR test sonuçlarına körleştirilen iki farklı radyolog tarafından CORADS sınıflamasına göre ayrı ayrı yorumlandı ve daha sonra ortak değerlendirme ile konsensüs sağlandı. Klinik, laboratuvar ve görüntüleme bulguları ile çoklu regresyon modellemesi yapıldı.

Bulgular: Çalışmaya 38 RT-PCR pozitif, 62 RT-PCR negatif olmak üzere toplam 99 hasta dahil edildi. Nötrofil/ lenfosit oranı (NLR) ve lenfosit sayıSı, RT-PCR pozitif hastalarda istatistiksel olarak anlamlı düzeyde daha düşüktü (sırasıyla $p=0,038, p=0,041$ ). Benzer şekilde, pozitif hastalarda CRP değerlerinin istatistiksel olarak anlamlı düzeyde düşük olduğu gözlendi $(p=0,029)$. RT-PCR (+) ile RT-PCR (-) ancak toraks BT 'si CO-RADS evrelemesine göre pozitif olan hastaların karşılaştırmalarında, RT-PCR (-) ancak toraks BT pozitif olan grupta anlamlı şekilde WBC, LDH ve CRP değerlerinin daha yüksek olduğu görüldü (sırasıyla $p=0,001, p=0,033$, $p=0,004)$. Öksürük, WBC, LDH, CRP değerleri ve toraks BT skoru kullanılarak geliştirilen modelde en yüksek AUC değeri elde edilmiş, RT-PCR pozitifliğini ayırt etmede başarılı olabileceği görüldü (AUC=0,725, \%95 $\mathrm{Cl}: 0,619-0,830)$.

Sonuç: Klinik bulgular varlığında RT-PCR pozitifliğini beklemeden COVID-19 uyumlu BT bulguları (CO-RADS'ye göre evre 4-5) ile yüksek WBC, CRP VE LDH varsa COVID-19 olasılığı artacaktır.

Anahtar kelimeler: CO-RADS, olası COVID-19, RT-PCR, SARS-CoV-2.

Uğurlu E, Çetin N, Ufuk F, Yiğit N, Yavaş HG, Kolak S, Çalışkan A, Dursunoğlu N, Başer S, Altınışık G, Pekcan S. Olası ve kesin COVID-19 vakalarının sosyodemografik, klinik, radyolojik ve laboratuvar bulgularının retrospektif olarak karşılaştırılması. Pam Tıp Derg 2021;14:706-716.

\section{Introduction}

Cases of the New Corona Virus infection first appeared in China in December 2019 after which it spread globally in a very short amount of time. The World Health Organization (WHO) declared a global pandemic on March 11, 2020 [1]. Coronavirus disease (COVID-19) is the name given to a syndrome caused by the new coronavirus renamed as SARS-CoV-2 due to its resemblance of the severe acute respiratory syndrome CoV (SARS-CoV) [2].

The first step in diagnosing the disease is the epidemiological history of the patient such as the trips made to regions where the disease is present, contact with sick people or complaints of fever during the previous two weeks. The second stage is the presence of bilateral opacities in the computed chest tomography (CT) taken due to symptoms of fever, coughing or shortness of breath [3].

Our Ministry of Health issued a guideline on March 25, 2020 following the first case in Turkey [4]. The definitions for probable and definitive cases were made in this guideline. Definitive diagnosis is made by detecting SARS Co-V-2 using Real Time Reverse Transcriptase Polymerase Chain Reaction (RT-PCR) method on the swab samples obtained from the nasopharynx or oropharynx of the patient. All others are considered under the definition of probable case.
Based on the latest reports, the sensitivity of RT-PCR varies between $60-71 \%$ [5-7]. As can be understood from these ratios, some of the cases are accepted and treated as probable cases according to clinical and computed chest tomography (CT) findings.

The aim of our study was to determine the number of probable and definitive cases among the patients hospitalized at our clinic and to contribute to the literature by examining the differences if any between the sociodemographic, clinical, chest CT and laboratory findings between these two groups.

\section{Materials and method}

\section{Study population}

All patients hospitalized at the department of pulmonology service between March 13 as the date of the first case and May 5 were included in the study. It was observed when the hospitalization criteria of the patients were examined that patients were hospitalized in cases of at least one of the fever or acute respiratory tract disorder symptoms and findings (coughing and labored breathing) along with the failure to explain the clinical table with a different reason/ disease as well as history within the past 14 days of visiting a foreign country with COVID-19 or having a relative/friend visiting a foreign country with COVID-19 within the past 14 days or coming into close contact with a definitive COVID-19 case within the past 14 days prior to 
the onset of at least one of the symptoms and findings of the disease (coughing and shortness of breath). Patients with positive RT-PCR test results were accepted as definite cases. No RT-PCR test result or negative but which is not considered as COVID-19 patients with clinical and radiological findings were considered as possible cases. Patient ward files and hospital data management system were examined. Patients with incomplete clinical and laboratory data or those with severe artefact observed in the chest CT were excluded from the study. In total, 99 patients who meet the aforementioned criteria were included in the study.

\section{RT-PCR}

For RT-PCR nasopharyngeal samples were acquired from each patient at the time of hospitalization. Tests were repeated throughout the hospitalization period for patients with negative test results. Bio-speedy COVID-19 RT-qPCR Detection Kit (1000-test version 2) developed in cooperation with TR Ministry of Health General Directorate of Public Health and Bioksen Company was used for detecting the SARS-CoV-2 virus.

\section{Radiologist interpretation}

The required chest CT for all patients hospitalized is shown in Figure 1. Chest CT images were obtained using a multidetector CT system (Brilliance 16, Philips Medical Systems) at deep inspiration in the supine position. The chest CT parameters were 1.5 $\mathrm{mm}$ slice thickness, $250 \mathrm{~mm}$ field of view, 100120 kilovoltage peak (kVp) tube voltage, 50-100 $\mathrm{mA}$ tube current, and $512 \times 512$ matrix. Chest CT findings of the patients were interpreted by two radiologists separately according to the CO-RADS [8] classification blinded to clinical and PCR test results of the patients (Table 1). Two radiologists re-evaluated the CT images with stage difference according to CO-RADS based on their initial evaluations and reached a consensus. The CT scans of stage 4 and 5 patients according to CO-RADS classification were evaluated as radiologically COVID-19 positive. The typical radiological characteristics for COVID-19 are presented in Table 2 [8].

This study was carried out in accordance with the Helsinki Declaration and was approved by the Ethical Council of our university with the decree dated 14.04.2020 and numbered 07.

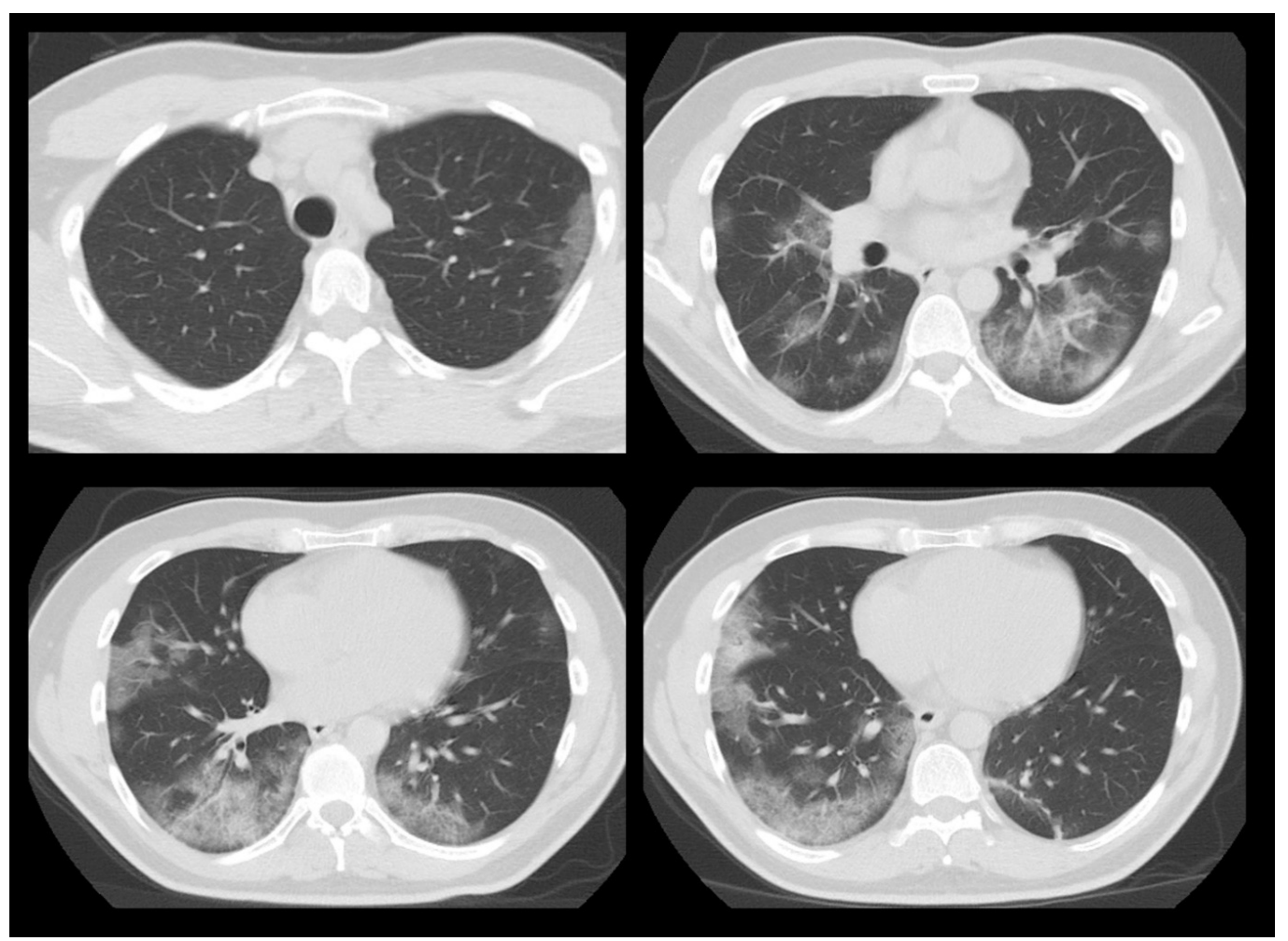

Figure 1. CT sections of the patient whose thorax CT was reported as CO-RADS 5; patchy subpleural and bilateral ground glass opacities 
Table 1. CO-RADS classification

\begin{tabular}{|c|c|c|}
\hline \multicolumn{3}{|c|}{$\begin{array}{c}\text { CO-RADS* } \\
\text { (COVID-19 Reporting and Data System) }\end{array}$} \\
\hline & $\begin{array}{l}\text { Level of suspicion for pulmonary } \\
\text { involvement of COVID-19 }\end{array}$ & Brief \\
\hline CO-RADS 0 & Not interpretable & Scan technically insufficient for assing a score \\
\hline CO-RADS 1 & Very low & Normal or non infectious \\
\hline CO-RADS 2 & Low & Typical for other infection but not COVID-19 \\
\hline CO-RADS 3 & Equivocal/unsure & $\begin{array}{l}\text { Features compatible with COVID-19, but also } \\
\text { other diseases }\end{array}$ \\
\hline CO-RADS 4 & High & Suspicious for COVID-19 \\
\hline CO-RADS 5 & Very high & Typical for COVID-19 \\
\hline CO-RADS 6 & Proven & RT-PCR positive for SARS-CoV-2 \\
\hline
\end{tabular}

${ }^{*}$ Referances [8]

Table 2. Typical CT findings of COVID-19 pulmonary involvement*

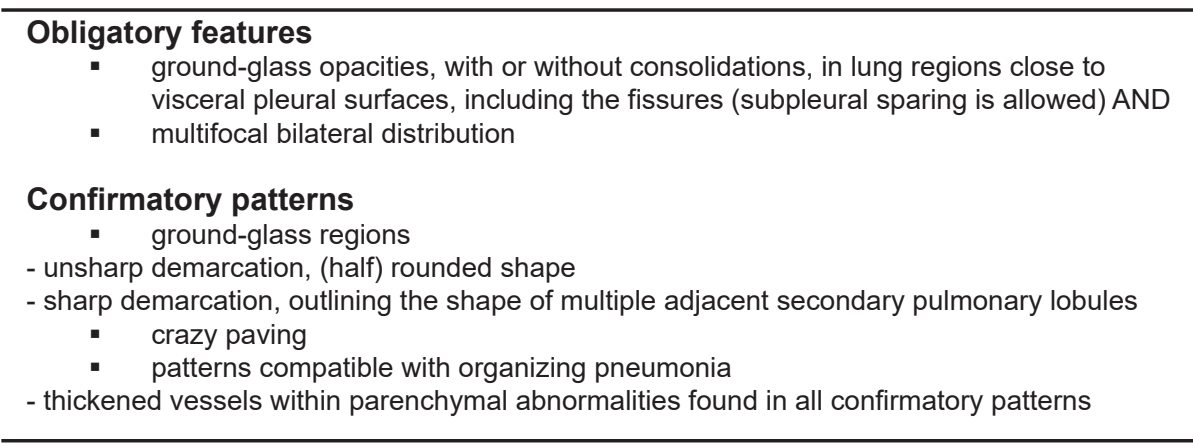

${ }^{*}$ Referances [8]

An application was made for our study with the form named 2020-04-30T15_15_59 and approval was obtained from the Ministry of Health.

\section{Statistical analysis}

A statistical software package (IBM SPSS Statistics 25 software (Armonk, NY: IBM Corp.)) was used to perform all analyses. Continuous variables were expressed as median and range (minimum - maximum values), categorical variables were expressed as counts (percentages). Shapiro-Wilk and Kolmogorov Smirnov tests were used for testing normality. For independent groups comparisons, we used Independent samples $t$ test when parametric test assumptions were provided, and Mann-Whitney $U$ test were used when parametric test assumptions were not provided. To determine the factors which are affecting PCR results, we used Multiple
Logistic Regression models. Accuracy, sensitivity, specificity were used for to analyse the performance of PCR and bt measurements. Also; Roc analysis was performed with the predicted probabilities obtained from logistic regression models to examine the estimation level of pcr results of models established with clinical variables. $p$ value less than 0.05 was considered statistically significant.

\section{Results}

The clinical and sociodemographic characteristics of the patients are shown in Table 3. There were 61 RT-PCR negative patients and 38 RT-PCR positive patients. The most frequent symptoms were coughing with $80.81 \%(n=80)$, fatigue with $55.56 \%(n=55)$, shortness of breath with $50.51 \%(n=50)$ and fever with $48.5 \%(n=48)$. Fever complaints were observed more at a statistically significant level in RT-PCR positive patients $(p=0.034)$ and fever was also observed 
Table 3. Demographic and clinical characteristics

\begin{tabular}{llll}
\hline Characteristic & $\begin{array}{l}\text { PCR positive } \\
(\mathbf{n = 3 8 )}\end{array}$ & $\begin{array}{l}\text { PCR negative } \\
(\mathbf{n = 6 1 )}\end{array}$ & $\boldsymbol{p ~ v a l u e *}^{*}$ \\
\hline Age, year (median-range) & $50.5(19-99)$ & $48(20-87)$ & 0.892 \\
Sex, $\mathbf{n}(\%)$ & & & \\
Female & $12(31.58)$ & $24(39.34)$ & 0.435 \\
Male & $26(68.42)$ & $37(60.66)$ &
\end{tabular}

Smoke, n (\%)

Non smoker

Ex smoker

Smoker

Comorbidities, $\mathbf{n}(\%)$

Diabetes

$6(15.79)$

Cardiovascular disease

$9(23.68)$

Chronic lung disease

Malignancy

Nervous system disease

Hypertension

Rheumatological disorders

İmmunosuppression

Signs and symptoms, $\mathrm{n}(\%)$

Cough

Fatigue

Fever

Dyspnea

Myalgia

Expectoration

Headache

Nausea, vomiting

Diarrhea

Loss of taste or smell

Rhinorrhea

Sore throat

Dizziness

$2(5.26)$

0

9 (23.68)

1 (2.63)

1 (2.63)

$\begin{array}{ll}21(55.26) & 32(52.46) \\ 13(34.21) & 14(22.95) \\ 4(10.53) & 15(24.59)\end{array}$

$6(15.79)$

$29(76.32)$
$24(63.16)$
$23(60.5)$
$16(42.11)$
$12(31.58)$
$8(21.05)$
$8(21.05)$
$6(15.79)$
$5(13.16)$
$3(7.89)$
$2(5.26)$
$2(5.26)$
0

51 (83.61)

0.370

31 (50.82)

0.230

25 (41)

0.05

34 (55.74)

0.187

15 (24.59)

0.448

14 (22.95)

0.825

$9(14.75)$

0.419

5 (8.2)

0.326

7 (11.48)

1

7 (11.48)

0.737

0

0.145

5 (8.2)

0.704

2 (3.28) 
to be higher at a statistically significant level at the time of application $(p=0.008)$. Hospitalization durations were observed to be longer at a statistically significant level for positive patients $(p=0.0001)$. The most frequently accompanying diseases were hypertension with $30.3 \%(n=30)$, chronic lung disease with $25.25 \% \quad(n=25)$, cardiovascular diseases with $18.18 \%(n=18)$, diabetes mellitus with $18.18 \% \quad(n=18)$ and malignities with $8.08 \%(n=8)$.

The comparison of the laboratory findings of the patients are shown in Table 4. WBC value was observed to be higher at a statistically significant level in negative patients $(p=0.0001)$. Neutrophil-to-lymphocyte ratio (NLR) values and lymphocyte count were lower at a statistically significant level in positive patients (respectively $p=0.038, p=0.041)$. Similarly, CRP values were observed to be lower at a statistically significant level in positive patients $(p=0.029)$. Table 5 presents the comparison made between patients with RT-PCR (+) and RT-PCR (-) but with positive chest CT findings according to CO-
RADS staging. It was observed as a result of that WBC, LDH and CRP values were high at a statistically significant level in the group with RT-PCR (-) but with positive chest CT findings. $(p=0.001, p=0.033, p=0.004)$.

The study flowchart including the chest CT and PCR assessments of our patients is presented in Figure 2. The sensitivity and specificity of chest CT were determined as $71 \%$ and $39 \%$ respectively.

We examined the distinctiveness with regard to RT-PCR results of the model examined via ROC analysis based on the result probabilities acquired from the model developed via multiple logistic regression method using the WBC, LDH, CRP, Ferritin, lymphopenia, chest CT score, coughing, fatigue and fever variables. It was observed that the highest $A \cup C$ value is obtained from the model developed using the WBC, LDH, $\mathrm{CRP}$, chest $\mathrm{CT}$ score and coughing parameters (AUC=0.725, 95\% Cl:0.619-0.830) and that it displays the highest success in distinguishing RT-PCR. This is shown in Figure 3.

Table 4. Laboratory parameters

\begin{tabular}{llll}
\hline $\begin{array}{l}\text { Parameters } \\
\text { (median-range) }\end{array}$ & $\begin{array}{l}\text { PCR positive } \\
(\mathbf{n}=38)\end{array}$ & $\begin{array}{l}\text { PCR negative } \\
\text { (n=61) }\end{array}$ & p value* \\
\hline Hemoglobin (K/uL) & $13.95(9.3-16.9)$ & $13.4(4.4-17.2)$ & 0.194 \\
White blood cells count (K/uL) & $5.83(3.36-16.41)$ & $9.4(1.14-30.11)$ & $<0.001$ \\
Lymphocyte count (K/uL) & $1.43(0.33-3.78)$ & $1.59(0.41-10.64)$ & 0.041 \\
NLR & $2.46(0.1-24.24)$ & $3.92(0.28-36.64)$ & 0.038 \\
LDH U/L & $214(136-417)$ & $244.5(128-840)$ & 0.06 \\
CRP (mg/L) & $18.23(0.35-213.5)$ & $38.83(0.62-400)$ & 0.029 \\
Procalcitonin (ng/mL) & $0.07(0.02-1.26)$ & $0.07(0.02-8.7)$ & 0.774 \\
Ferritin (ug/L) & $160.8(5.61-1698)$ & $154(4.89-1731)$ & 0.478 \\
D-dimer (ng/mL) & $251(28-1972)$ & $287(79-8160)$ & 0.09 \\
Troponin (ng/L) & $4.26(1.07-63.75)$ & $4.93(3-86.28)$ & 0.505 \\
25-OH-Vitamin D (ug/L) & $12.87(3-100)$ & $11.45(5.03-100)$ & 0.949 \\
\hline
\end{tabular}

NLR: neutrophil-to-lymphocyte ratio; LDH: Lactate Dehydrogenase; CRP: C-reactive protein 


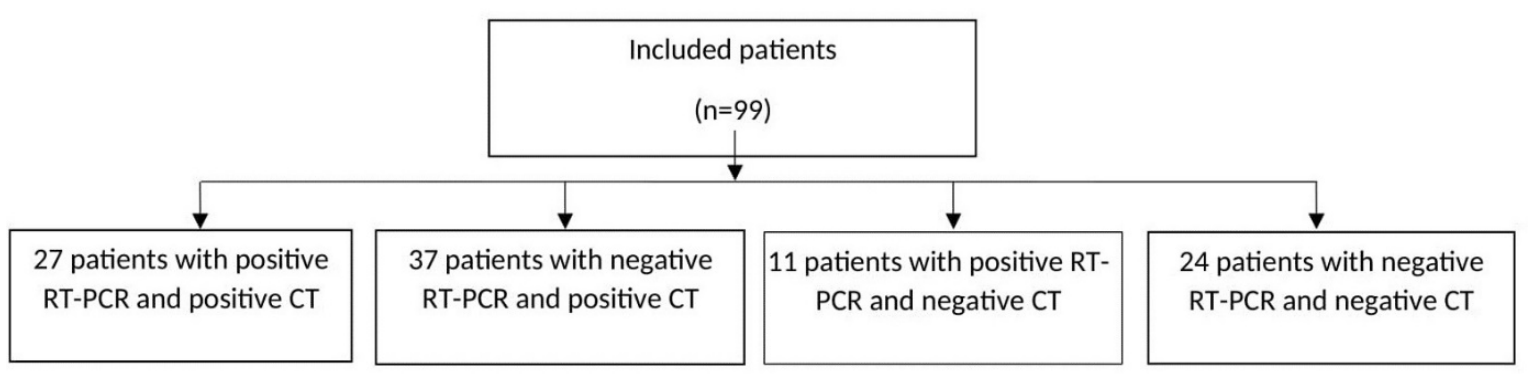

Figure 2. A flow chart showing the chest CT and PCR assessments of our patients

Table 5. Comparison of clinical features of PCR positive patients and PCR negative, BT positive (CO-RADS 4/5) patients

\begin{tabular}{llll}
\hline $\begin{array}{l}\text { Features } \\
\text { (median-range) }\end{array}$ & $\begin{array}{l}\text { PCR positive } \\
(\mathbf{n = 3 8})\end{array}$ & $\begin{array}{l}\text { PCR negative BT CO-RADS 4/5 } \\
(\mathbf{n = 6 1 )}\end{array}$ & $\boldsymbol{p ~ v a l u e * ~}^{*}$ \\
\hline Hemoglobin (K/uL) & $13.95(9.3-16.9)$ & $13.4(4.4-17.2)$ & 0.464 \\
White blood cells count (K/uL) & $5.83(3.36-16.41)$ & $8.97(1.14-30.11)$ & $\mathbf{0 . 0 0 1}$ \\
Lymphocyte count (K/uL) & $1.43(0.33-3.78)$ & $1.55(0.41-3.34)$ & $\mathbf{0 . 0 8 1}$ \\
NLR & $2.46(0.1-24.24)$ & $4.25(0.94-36.64)$ & 0.068 \\
LDH U/L & $214(136-417)$ & $267(128-840)$ & $\mathbf{0 . 0 3 3}$ \\
CRP (mg/L) & $18.23(0.35-213.5)$ & $69.73(2.17-362.29)$ & $\mathbf{0 . 0 0 4}$ \\
Procalcitonin (ng/mL) & $0.07(0.02-1.26)$ & $0.06(0.02-5.19)$ & 0.413 \\
Ferritin (ug/L) & $160.8(5.61-1698)$ & $186(13.48-1731)$ & 0.778 \\
D-dimer (ng/mL) & $251(28-1972)$ & $309(91-2567)$ & 0.065 \\
Troponin (ng/L) & $4.26(1.07-63.75)$ & $4.64(3-86.28)$ & 0.733 \\
25-OH-Vitamin D (ug/L) & $12.87(3-100)$ & $13.22(5.03-100)$ & 0.495 \\
Time between first pcr and complaints & $3(0-16)$ & $4(0-16)$ & 0.153 \\
\hline
\end{tabular}

NLR: neutrophil-to-lymphocyte ratio; LDH: Lactate Dehydrogenase; CRP: C-reactive protein

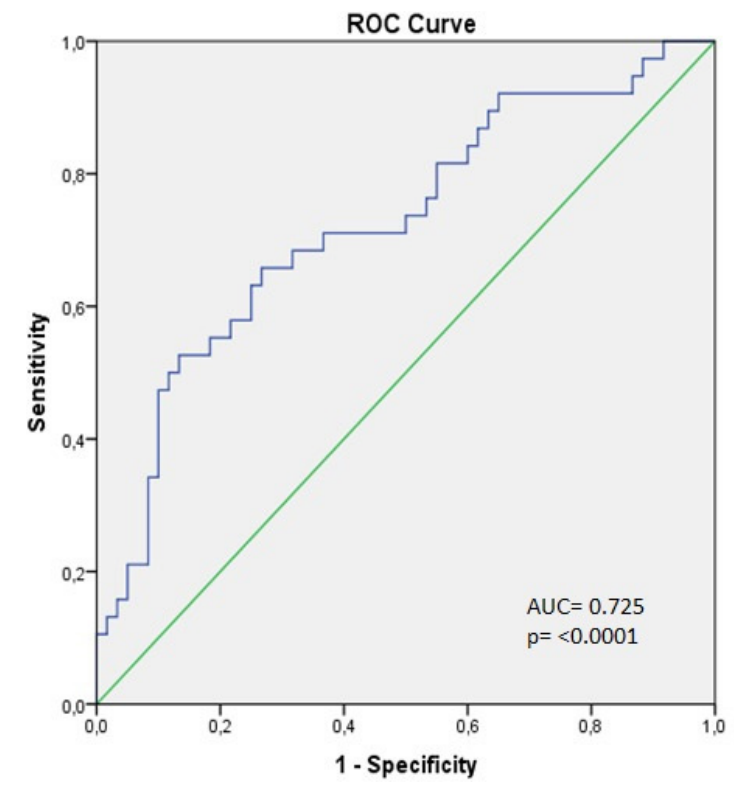

Figure 3. ROC curve of the model developed using the WBC, LDH, CRP, chest CT score and coughing parameters 


\section{Discussion}

The sensitivity of the RT-PCR test varies between $60-71 \%$ based on the latest reports [5-7]. The sensitivity of the RT-PCR test was determined to be lower in our study with $42.19 \%$ compared to the findings in literature. The ratio of detecting the virus from the nasopharyngeal samples taken for the RT-PCR test was $63 \%$, while the ratio for the oropharyngeal samples was $32 \%$ [9]. The accuracy of the RT-PCR test can be affected from many factors such as the viral load in the respiratory tract, source of the sample, sampling procedures and timing, quality control of the test and the natural performance of the test kits [10]. The viral load in the throat samples peaks in around 5-6 days and the viral load in the sputum samples is significantly greater than that of the throat samples [11]. If the virus has a tendency to infect the lungs rather than the upper respiratory tract, it may not be isolated in the nasopharyngeal or oropharyngeal samples [12]. RT-PCR test could not be made at our hospital during the onset of the pandemic and the samples were sent to the capital city with the results taking about 2-3 days. Our hospital became the first laboratory for the whole province after the test was started at our hospital as well. Treatment was started for the first tests sent to the capital city for Ministry of Health Laboratory without waiting for the results since it took a long time for the results to reach us. Starting the treatment without waiting for the test results reduced the probability of a positive result in the second test. When the literature is examined that the ratio of detecting the virus in the sputum and bronchoscopic lung lavages of the RT-PCR samples is much greater than detecting in the nose or throat due to the fact that the main invasion location of SARS CoV-2 is the lower respiratory tract, it is indicated that it is necessary to examine the sputum or bronchoscopic lavage or stool as well for the RT-PCR samples that were negative in the nose or throat [13]. However, RT-PCR was not examined in the sputum since sputum complaint was only present in a small number of patients. Since contamination will increase in bronchoscopic procedures, it was not performed for protecting the healthcare staff, diagnosis was placed, and treatment was started by taking into consideration the clinical findings, epidemiologic history, chest CT and laboratory findings. When all these factors are taken into consideration, we can state the reason for the low sensitivity of the RT-PCR samples acquired from the patients. As a general evaluation, we are of the opinion that the RT-PCR test is not reliable and independent for the diagnosis and screening of COVID-19.

The sensitivity of chest CT was observed in our study as $71 \%$ while the specificity was determined as $39 \%$. Ai et al. [5] carried out a study on 1014 patients in China as a result of which the sensitivity and specificity values were determined for chest CT as $97 \%$ and $25 \%$ respectively. Sensitivity was determined to be much higher in this study compared to our own findings. A reason for this may be the fact that in the study by Ai et al. [5], the radiologists had prior knowledge of the epidemiologic histories and clinical symptoms (fever/coughing) of their patients contrary to our study. The reason for blindness of radiologist to the clinical finding in our institution is the timing of radiological examination at emergency room stay and the urgency for evaluating patients according to COVID-19 possibility. Classification can be put forth as a second reason. In the study by $\mathrm{Ai}$ et al. [5], radiologists classified the CTs either as positive or negative. Whereas CO-RADS classification was used in our study and the responses were classified under five stages as negative, low probability, uncertain, high probability and very high probability. Hence, we are of the opinion that sensitivity will be increased by giving a response as positive or negative. Fang et al. [6] carried out a study on 51 patients as a result of which it was concluded that the sensitivity of chest CT is $98 \%$, however it has not been clearly indicated in the study how radiologists evaluate the CTs and whether they have prior knowledge on the patients or not. He et al. [14] carried out a study on 82 patients as a result of which chest CT sensitivity was determined as $77 \%$. The radiologists in this study also had prior knowledge on the epidemiological histories and clinical characteristics of their patients contrary to our study.

The most frequently observed symptoms for COVID-19 patients were coughing with $80.81 \%$ (80), fatigue with $55.56 \%$ (55), shortness of breath with $50.51 \%(50)$ and fever with $44.44 \%$ (44). The other less frequently observed symptoms were sputum with $22.22 \%$ (22), diarrhea with $12.12 \%$ (12), loss of taste- 
scent with $10.1 \%(10)$, throat ache with $7.07 \%$ (7). It can be observed when the literature is examined that the most frequently observed symptoms are fever, coughing, fatigue and labored breathing, as was the case in our study [15-17]. Fever was ranked as number 1 in all these studies followed by coughing. While fever is ranked last at, number four in our study among all these symptoms. The duration of time that passed between the starting of the complaints and applying to the hospital was determined in our study as $4.15 \pm 2.93$ days. This was not mentioned in other studies. This may be the reason for the change in the order of the most frequently observed symptoms.

The value of WBC was observed to be higher at a statistically significant level in patients with RT-PCR (-). Lymphocyte values were observed to be lower at a statistically significant level in patients with RT-PCR(+). These findings are in accordance with the literature $[14,16,18$, 19]. Lymphopenia is an effective and reliable indicator for determining hospitalization and severity of the disease for COVID-19 [20, 21]. Endothelium dysfunction may lead to the damaging of intercellular connections, death of endothelium cells thus resulting in the disruption of the blood tissue barrier thereby leading to leucocyte adhesion and extravasation for elderly individuals and chronic patients. This can explain lymphopenia in severe COVID-19 patients [22]. The connection between endothelium dysfunction and lymphopenia has been proven for community-acquired pneumonia [23].

It was observed as a result of the comparison made between the laboratory findings of patients with RT-PCR (+) and with RT-PCR (-) but with chest CT findings positive for COVID-19 that WBC, LDH and CRP were higher at a statistically significant level in patients with RTPCR (-) but with chest CT findings (+). CRP and LDH are acute phase reactants and have been used in the diagnosis and prognosis assessment of SARS and MERS, which are previous coronavirus contagions [24]. CRP and LDH were high in COVID-19 as well and have been used for evaluating prognosis [25-27]. Combination of hypoalbuminemia, lymphopenia and high CRP and LDH may predict severe lung damage in COVID-19 patients after admission to the hospital [27]. High values of LDH and CRP in our patients with positive chest CT support these literature findings. Qin et al. [28] carried out a study on 452 patients by classifying the COVID-19 patients as severe and non-severe as a result of which it was determined that the WBC levels were higher in the severe group patients in comparison with the patients in the other group. The course of the COVID-19 disease has been evaluated in three stages with ground glass infiltrations indicated as the $3^{\text {rd }}$ and final stage [29]. As shown in stage 3 patients, the detection of higher WBC values in patients with infiltrates on chest CT in our study is consistent with the literature.

In our study, modeling was done with WBC, $\mathrm{LDH}, \mathrm{CRP}$, chest CT and cough parameters. Similar to our study, Dofferhoff et al. [30] carried out a modelling study on 312 patients as a result of which a different algorithm was tried to be developed for diagnosis by classifying the patients into 3 groups as definitive COVID-19, strong suspicions on COVID-19 and lower suspicions on COVID-19 according to RT-PCR result, fever level, lymphopenia, LDH level and staging of chest CT based on CO-RADS staging.

The main limitation of our study was the low number of patients and that RT-PCR could not be performed at our hospital at the beginning of the epidemic with the samples being sent to capital city about $500 \mathrm{~km}$ away. We are of the opinion that the possible decreases in the quality of the test due to the probable negativities that may develop during transport since the test was performed in only one city in our country and all samples taken in the country were sent to this laboratory and due to the long waiting times of the samples prior to being worked on thereby leading to longer test result times in addition to the hectic work schedule of this laboratory. The test was performed with a busy schedule as well after we started working as the only laboratory performing the test in our institution. This led to delays for repeated tests and treatments were started without waiting for the tests since the results came in very late. Starting the treatment without waiting for the test results decreased the probability of a positive result in the second test. As indicated in the literature, it is suggested to check the sputum, bronchoscopic lavage fluid or stool for those with negative RT-PCR samples from the nose or throat. However, sputum test was not performed since it was present in a very 
small number of patients and for protecting the healthcare staff since interventional procedures such as bronchoscopy may increase the risk of contamination. These were among the other limitations of our study.

In conclusion, a definitive diagnosis cannot be placed for the COVID-19 disease except by isolating the SARS-CoV-2 virus in RT-PCR. Since the sensitivity of the RT-PCR method is very low, cases may be missed leading to problems with methods such as quarantine and isolation thus making it impossible to take the epidemic under control. It was determined as a result of the findings of our study that high serum WBC, CRP and LDH values are the laboratory findings that support this preliminary diagnosis of the clinician in cases with no PCR test result or negative, but with clinical and radiological suspected COVID-19. The probable diagnosis of the disease may be placed without the need for RT-PCR by way of various models using similar parameters with larger data sets.

Conflict of interest: No conflict of interest was declared by the authors.

\section{References}

1. Yan $\mathrm{Y}$, Shin $\mathrm{W}$, Pang $\mathrm{YX}$, et al. The first 75 days of novel coronavirus (SARS-CoV-2) outbreak: recent advances, prevention, and treatment. Int J Environ Res Public Health 2020;17:2323. https://doi.org/10.3390/ ijerph17072323

2. Sarzi Puttini P, Giorgi V, Sirotti S, et al. COVID-19, cytokines and immunosuppression: what can we learn from severe acute respiratory syndrome? Clin Exp Rheumatol 2020;38:337-342.

3. Wujtewicz M, Dylczyk Sommer A, Aszkiełowicz A, Zdanowski S, Piwowarczyk S, Owczuk R. COVID-19what should anaethesiologists and intensivists know about it? Anaesthesiol Intensive Ther 2020;52:34-41. https://doi.org/10.5114/ait.2020.93756

4. TC. Sağlık Bakanlığı Halk Sağlığı Genel Müdürlüğü COVID-19 (Sars-CoV-2) enfeksiyonu rehberi. Avaliable at: https://covid19bilgi.saglik.gov.tr/depo/rehberler/ COVID-19_Rehberi.pdf. Accessed March 20, 2021

5. Ai T, Yang Z, Hou H, et al. Correlation of chest CT and RT-PCR testing for coronavirus disease 2019 (COVID-19) in China: a report of 1014 cases. Radiology 2020;296:32-40. https://doi.org/10.1148/ radiol.2020200642

6. Fang $\mathrm{Y}$, Zhang $\mathrm{H}, \mathrm{Xie} \mathrm{J}$, et al. Sensitivity of chest CT for COVID-19: comparison to RT-PCR. Radiology 2020;296:115-117. https://doi.org/10.1148/ radiol.2020200432
7. Kanne JP, Little BP, Chung JH, Elicker BM, Ketai LH. Essentials for radiologists on COVID-19: an update-radiology scientific expert panel. Radiology 2020;296:113-114. https://doi.org/10.1148/ radiol. 2020200527

8. Prokop $M$, van Everdingen $W$, van Rees Vellinga $T$, et al. COVID-19 standardized reporting working group of the dutch radiological society. CO-RADS: a categorical CT assessment scheme for patients suspected of having COVID-19-definition and evaluation. Radiology 2020;296:97-104. https://doi.org/10.1148/ radiol.2020201473

9. Wang $W, X u Y, G a o R$, et al. Detection of SARSCoV-2 in different types of clinical specimens. JAMA 2020;323:1843-1844. https://doi.org/10.1001/ jama.2020.3786

10. Chan JFW, Yip CCY, To KKW, et al. Improved molecular diagnosis of COVID-19 by the novel, highly sensitive and specific COVID-19-RdRp/Hel real-time reverse transcription-PCR assay validated in vitro and with clinical specimens. J Clin Microbiol 2020;58:e0031020. https://doi.org/10.1128/JCM.00310-20

11. Pan $Y$, Zhang D, Yang P, Poon LLM, Wang Q. Viral load of SARS-CoV-2 in clinical samples. Lancet Infect Dis 2020;20:411-412. https://doi.org/10.1016/S14733099(20)30113-4

12. Chen M, An W, Xia F, et al. Clinical characteristics of rehospitalized patients with COVID-19 in China. J Med Virol 2020;92:2146-2151. https://doi.org/10.1002/ jmv.26002

13. Cao H, Ruan L, Liu J, Liao W. The clinical characteristic of eight patients of COVID-19 with positive RT-PCR test after discharge. J Med Virol 2020;92:2159-2164. https://doi.org/10.1002/jmv.26017

14. He JL, Luo L, Luo ZD, et al. Diagnostic performance between CT and initial real-time RT-PCR for clinically suspected 2019 coronavirus disease (COVID-19) patients outside Wuhan, China. Respir Med 2020;168:105980. https://doi.org/10.1016/j. rmed.2020.105980

15. Huang C, Wang Y, Li X, et al. Clinical features of patients infected with 2019 novel coronavirus in Wuhan, China. Lancet 2020;395:497-506. https://doi.org/10.1016/ S0140-6736(20)30183-5

16. Wang $\mathrm{D}, \mathrm{Hu} \mathrm{B}, \mathrm{Hu} \mathrm{C}$, et al. Clinical characteristics of 138 hospitalized patients with 2019 novel coronavirus-infected pneumonia in Wuhan, China. JAMA 2020;323:1061-1069. https://doi.org/10.1001/ jama.2020.1585

17. Chen N, Zhou M, Dong $X$, et al. Epidemiological and clinical characteristics of 99 cases of 2019 novel coronavirus pneumonia in Wuhan, China: a descriptive study. Lancet 2020;395:507-513. https:// doi.org/10.1016/S0140-6736(20)30211-7 
18. Huang $Q$, Deng $X, \mathrm{Li}$, et al. Clinical characteristics and drug therapies in patients with the common-type coronavirus disease 2019 in Hunan, China. Int J Clin Pharm 2020;42:837-845. https://doi.org/10.1007/ s11096-020-01031-2

19. Javanian M, Bayani M, Shokri M, et al. Clinical and laboratory findings from patients with COVID-19 pneumonia in Babol North of Iran: a retrospective cohort study. Rom J Intern Med 2020;58:161-167. https://doi.org/10.2478/rjim-2020-0013

20. Tan L, Wang $Q$, Zhang $D$, et al. Lymphopenia predicts disease severity of COVID-19: a descriptive and predictive study. Signal Transduct Target Ther 2020;5:33. https://doi.org/10.1038/s41392-020-0148-4

21. Bermejo Martin JF, Almansa R, Menéndez R, Mendez R, Kelvin DJ, Torres A. Lymphopenic community acquired pneumonia as signature of severe COVID-19 infection. J Infect 2020;80:23-24. https://doi.org/10.1016/j. jinf.2020.02.029

22. Bermejo Martin JF, Martín Fernandez M, López Mestanza C, Duque P, Almansa R. Shared features of endothelial dysfunction between sepsis and its preceding risk factors (aging and chronic disease). J Clin Med 2018;7:400. https://doi.org/10.3390/ jcm7110400

23. Menéndez R, Méndez R, Almansa R, et al. Simultaneous depression of immunological synapse and endothelial injury is associated with organ dysfunction in community-acquired pneumonia. J Clin Med 2019;8:1404. https://doi.org/10.3390/jcm8091404

24. Azkur AK, Akdis M, Azkur D, et al. Immune response to SARS-CoV-2 and mechanisms of immunopathological changes in COVID-19. Allergy 2020;75:15641581. https://doi.org/10.1111/all.14364

25. Zhou F, Yu T, Du R, et al. Clinical course and risk factors for mortality of adult inpatients with COVID-19 in Wuhan, China: a retrospective cohort study. Lancet 2020;395:1054-1062. https://doi.org/10.1016/S01406736(20)30566-3

26. Chen $\mathrm{T}, \mathrm{Wu} \mathrm{D}$, Chen $\mathrm{H}$, et al. Clinical characteristics of 113 deceased patients with coronavirus disease 2019: retrospective study. BMJ 2020;368:m1091. https://doi. org/10.1136/bmj.m1091

27. Liu Y, Yang Y, Zhang C, et al. Clinical and biochemical indexes from 2019-nCoV infected patients linked to viral loads and lung injury. Sci China Life Sci 2020;63:364374. https://doi.org/10.1007/s11427-020-1643-8

28. Qin C, Zhou L, Hu Z, et al. Dysregulation of immune response in patients with COVID-19 in Wuhan, China. Clin Infect Dis 2020;71:762-768. https://doi. org/10.1093/cid/ciaa248

29. Mason RJ. Pathogenesis of COVID-19 from a cell biology perspective. Eur Respir J 2020;55:2000607. https://doi.org/10.1183/13993003.00607-2020
30. Dofferhoff ASM, Swinkels A, Sprong T, et al. Diagnostic algorithm for COVID-19 at the ER. Ned Tijdschr Geneeskd 2020;164:D5042.

Ethical council approval: This study was conducted in accordance with the Declaration of Helsinki and was approved by the Pamukkale University Ethics Committee with the decree dated 14.04.2020 and numbered 07. It has also been approved by the Turkish Ministry of Health Scientific Research Platform.

The abstract of this study was presented as an oral presentation in the 41st National Congress of TUSAD - RESPIRATION 20120 Virtual Congress, 2-8 October 2020.

\section{Author contributions}

E.U., N.C., N.Y. constructed the main idea and hypothesis of the study. E.U., N.C., F.U., N.Y., A.C. developed the theory and organized the material method section. E.U., N.C., F.U., N.Y., H.G.Y., S.K., A.C. analyzed the data in the results section. The discussion section of the article was written by E.U., N.C., F.U., N.Y., H.G.Y., S.K., A.C., and N.D., S.B., G.A., S.P. reviewed, made the necessary corrections, and approved. Also, all authors discussed the whole study and approved its final version. 